\title{
MOLECULAR CONCEPTS OF MACROPHAGE TARGETING
}

\author{
Veaceslav Boldescu*, Valeriu Crudu, Natalia Sucman, Serghei Pogrebnoi, \\ Marina Zviaghințeva, Eugenia Stîngaci, Vsevolod Pogrebnoi, Fliur Macaev \\ Institute of Chemistry of Academy of Science of Moldova, 3, Academiei str., Chisinau MD-2028, Republic of Moldova \\ *e-mail: veaceslav.boldescu@gmail.com
}

\begin{abstract}
Macrophages play an important role in the pathological development of such disorders as cancer, inflammatory and certain infectious diseases, such as tuberculosis, HIV, dengue virus, and leishmaniasis. Therefore, macrophage targeting represents an important challenge in design of new medicines. This review gives a general presentation of small molecule-recognition concepts with application in drug design for macrophage targeting. It describes different mechanisms and systems for macrophage-targeted delivery, including ligands or small molecule motifs recognizable by macrophage specific proteins, like receptors (e. g. sialoadhesin, folate, galactose, mannose, $\beta$-glucan, and scavenger, tuftsin receptors) or enzymes (carboxylesterase-1), pathways for their obtaining and routes of their application.
\end{abstract}

Keywords: macrophage receptor targeting, macrophage enzyme targeting, inflammatory disorders, tuberculosis, cancer.

\section{Introduction}

Macrophages are an essential part of the mononuclear phagocyte system. They derive from bone marrow's monoblasts and promonoblasts, which are transformed in circulating monocytes. After migration in extravascular tissue, monocytes differentiate into macrophages [1]. Inflammatory monocytes differentiate into inflammatory or activated macrophages in inflamed or cancerous tissue, non-inflammatory monocytes infiltrate different organs and transform into residential macrophages [2,3]. Residential macrophages are presented in the central nervous system (microglia cells), connective tissue, gut, liver (Kupffer cells), lungs (alveolar macrophages), lymph nodes, bone marrow (osteoclasts), serous cavities, spleen, and thymus [2,3].

The main role of macrophages is host defence against many infectious agents. Besides, macrophages have been found to play an important part in the pathology of different diseases: atherosclerosis (foam cells) [4], cancer (tumourassociated macrophages) [5], infectious diseases, for which agents macrophages play a role of host cells (e. g. tuberculosis [6], HIV [7], leishmaniasis [8], dengue virus [9]), etc. Due to these findings, macrophages make an important target for drug development [10].

In the macrophage targeting, different concepts are applied. This review is mainly dedicated to use of small molecule-recognition mechanisms that include:

1) targeting macrophage receptors:

- sialoadhesin receptors

- folate receptors

- galactose receptors

- mannose receptors

- $\beta$-glucan receptors

- scavenger receptors

- tuftsin receptors

2) targeting specific macrophage enzymes:

- carboxylesterase-1

The review does not cover the application of antibodies in the macrophage targeting systems.

\section{Targeting macrophage receptors: \\ Sialoadhesin receptors}

Resident and activated macrophages are known to have high level of sialoadhesin receptors (Sn, Siglec-1, CD169) expression [11-13]. Sn studies indicate that this receptor most likely functions as a macrophage accessory molecule in a variety of cell-cell and cell-extracellular matrix interactions [14]. Chen et al. [15] proposed to use high affinity glican ligand, sialic acid, for decoration of PEGylated liposomes designed to target Sn/CD169 expressing macrophages. The synthesis of 3'-BPC NeuAc-PEGylated lipids, components of the liposomal wall, is presented in Scheme 1.

Nycholat et al. [16] have performed in silico-aided design of a glycan ligand of sialoadhesin for in vivo targeting of macrophages. As a result, the most potent of the selected ligands, 9-N-(4H-thieno[3,2-c]chromene-2-carbamoyl)Neu5Aca2-3Gal $31-4 \mathrm{GlcNAc}$ ( ${ }^{\mathrm{TCC}} \mathrm{Neu} 5 \mathrm{Ac}$ ), was conjugated to lipids for display on a liposomal nanoparticle, which later showed high level of in vivo affinity toward Sn-positive macrophages. 


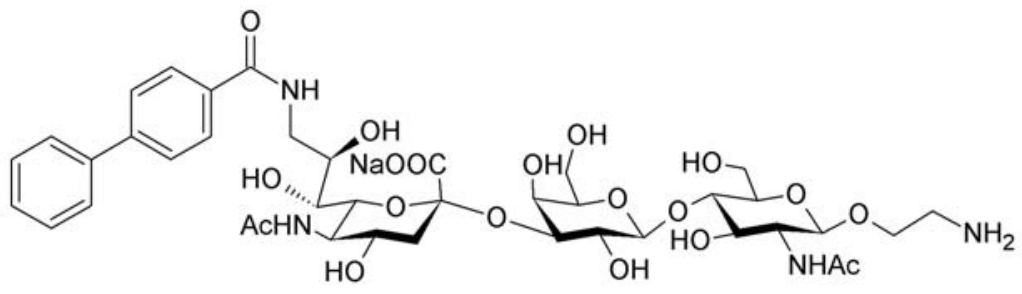

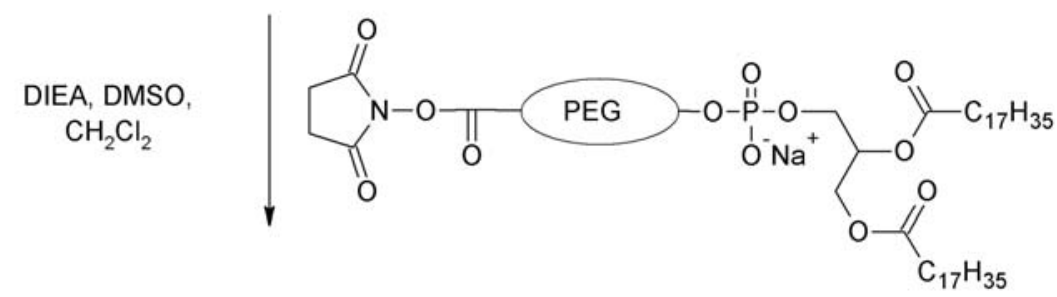

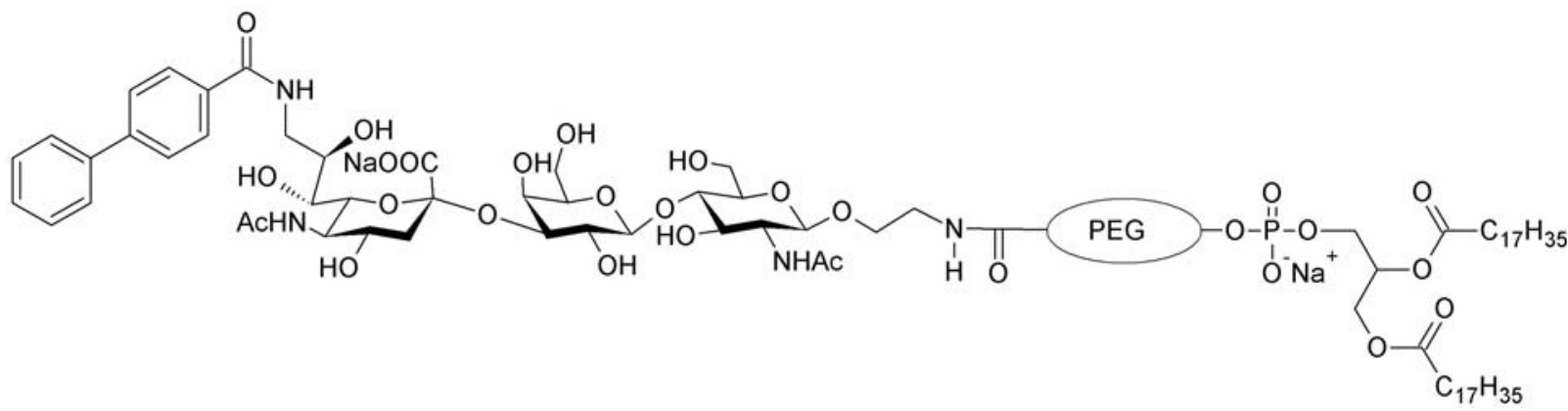

Scheme 1. Synthesis of 3'- ${ }^{\mathrm{BPC}}$ NeuAc-PEGylated lipids. Sialic acid ligand coupled to an N-hydroxysuccinimide-activated PEGylated lipid [15].

A review presenting some aspects of $\mathrm{Sn}$ structure and function and summarizing up-to-date progress on the identification of sialic acid based high-affinity ligands of certain well explored Siglec receptors has been done by Magesh et al. [17].

\section{Folate receptors}

Folate receptors [FRs] can also be used as targets for macrophage specific delivery. Thus, folate-targeted dendrimeric conjugates with folic acid and methotrexate showed efficiency in the treatment of inflammatory arthritis in a rat arthritic model [18]. The general scheme of the dendrimer conjugate obtaining is presented in the Scheme 2.

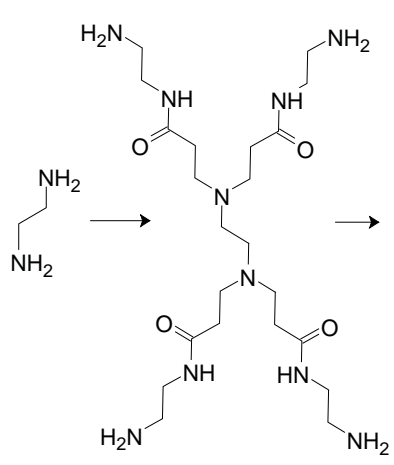

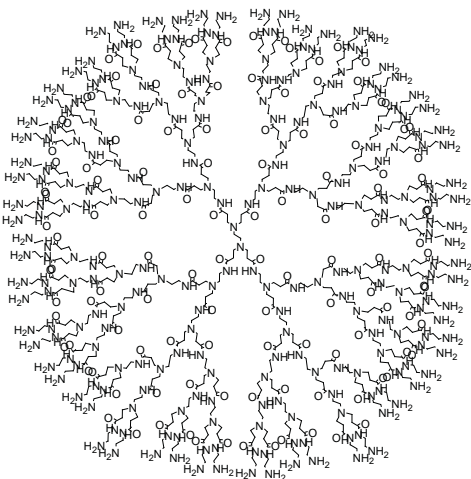

G5

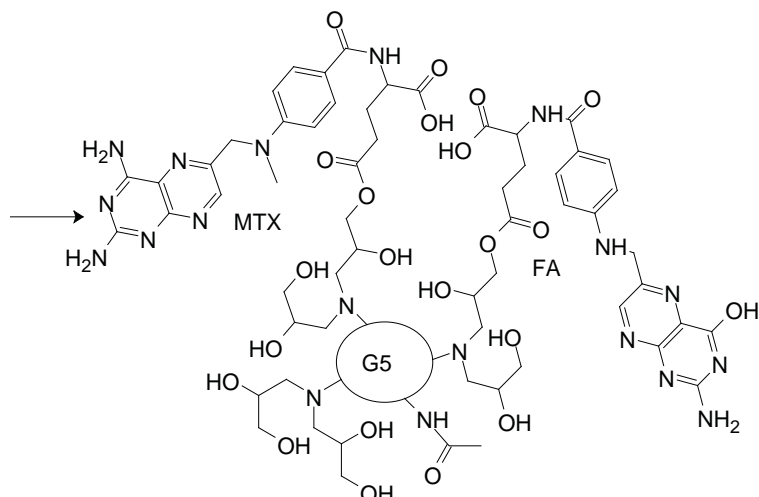

$\mathrm{OH}$

Scheme 2. Scheme of preparation of folate-targeted dendrimeric conjugates with folic acid and methotrexate [18]. 
In short, it includes repetition of Michael addition of methylacrylate to EDA followed by condensation reaction (amidation), which finally gives the $5^{\text {th }}$ generation dendrimer (G5). The G5 then is partially acetylated (60 - 70\%), the folic acid (FA) is incorporated through amide linkage, followed by glycidolation to fully neutralize the surface. In the end, the methotrexate (MTX) is conjugated through ester linkage. A similar study dedicated to the synthesis of folatedendrimer conjugates as suitable vehicles for site specific delivery of anti-arthritic drug (indomethacin) to inflammatory regions in arthritic rats was performed by Chandrasekar et al. [19]. Presumably the obtained conjugates targeted FRs in macrophages.

Turk et al. have demonstrated that folate-conjugated liposomes preferably target tumour-associated macrophages of ovarian carcinoma [20]. As well, application of a ${ }^{99 \mathrm{~m}} \mathrm{Tc}$ chelator conjugated with folate for selectively targeted imaging of sites of inflammation in adjuvant-induced arthritis has been suggested [21]. A good review on targeting macrophagial folate receptors in rheumatoid arthritis has been realized by Paulos et al. [22].

Recently, synthesis of a novel folate receptor ligand [18F] fluoro-PEG-folate was proposed by Gent et al. [23]. [18F]fluoro-PEG-folate 1 was synthesized in a two-step procedure (Scheme 3). For this, [18F]succinylfluorobenzoate ([18F]SFB) 4 was obtained by fluorination of the SFB precursor 2 . The labeled precursor 3 was then deprotected with tetrapropylammonium hydroxide and treated with tetramethyl-o-(N-succinimidyl) uranium tetrafluoroborate to generate [18F]SFB 4. Then, PEG-folate precursor 5 was added into solution of [18F]SFB 4 in acetonitrile and reacted for 30 minutes at ambient temperature with formation of [18F]fluoro-PEG-folate [23].

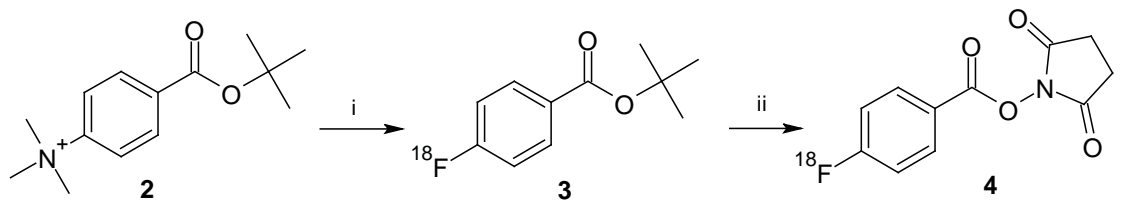<smiles>NCCNC(=O)CCOCCOCCNC(=O)CCC(NC(=O)c1ccc(NCc2cnc3nc(N)nc(O)c3n2)cc1)C(=O)O</smiles><smiles>Nc1nc(O)c2nc(CNc3ccc(C(=O)NC(CCC(=O)NCCOCCOCCC(=O)NCCNC(=O)c4ccc(F)cc4)C(=O)O)cc3)cnc2n1</smiles>

Scheme 3. Synthesis of [18F]fluoro-PEG-folate. Conditions: i - [18F]fluoride, acetonitrile, K[2.2.2], $\mathrm{K}_{2} \mathrm{CO}_{3}, 82^{\circ} \mathrm{C}, 10 \mathrm{~min}$; ii - tetrapropylammonium hydroxide, then, tetramethyl-o-(N-succinimidyl)uranium tetrafluoroborate, 30 to $50 \%$ (for $\mathrm{i}$ and $\mathrm{ii}$ ); iii - $150 \mathrm{mM}$ borate buffer, $30 \mathrm{~min}$, room $\mathrm{t}^{\circ}, 70$ to $90 \%$ [23].

\section{Galactose receptors}

Macrophage targeting can be also realized through galactose receptor (GR). Experiments performed by Shimada et al. have demonstrated that liposome surface-exposed galactose residues are effectively recognized by the galactose particle receptor on the Kupffer cells [24].

Haensler and Schuber [25] were among first who prepared neo-galactosylated liposomes and studied their interaction with mouse peritoneal macrophages. Compared to the control vesicles, the neo-galactosylated liposomes (containing $15 \mathrm{~mol} \%$ galactose) in vitro presented an increased binding to the macrophages. At $4^{\circ} \mathrm{C}$, the specific binding was about 2-fold, whereas at $37^{\circ} \mathrm{C}$ it was increased to about 4-5-fold. This differential binding was not affected by serum and was highly dependent on the degree of galactosylation of the liposomes, i.e. a threshold value of 5 mol\% was needed to observe an increased binding of the targeted vesicles to the macrophages.

Later, Haensler and Schuber [26] studied the influence of the galactosyl ligand structure on the interaction of galactosylated liposomes with mouse peritoneal macrophages. As a result, they found that the interaction of the galactosylated liposomes with the macrophage lectin was remarkably sensitive to the topology of the ligands: a spacerarm length about $3 \mathrm{~nm}$ was necessary. At the same time, in contrast to the results obtained with the galactose receptors of 
other cells, the triantennary structure that was studied in comparison with monoantennary one did not provide additional binding.

GR was proposed for targeting by low density lipoprotein (LDL) nanoparticles designed to deliver antigens to Kupffer cells, a group of macrophages residing in liver [27]. For this, LDL was conjugated with fluoresceinated ovalbumin (FLUO-OVA) and lactobionic acid as main ligand (Scheme 4).

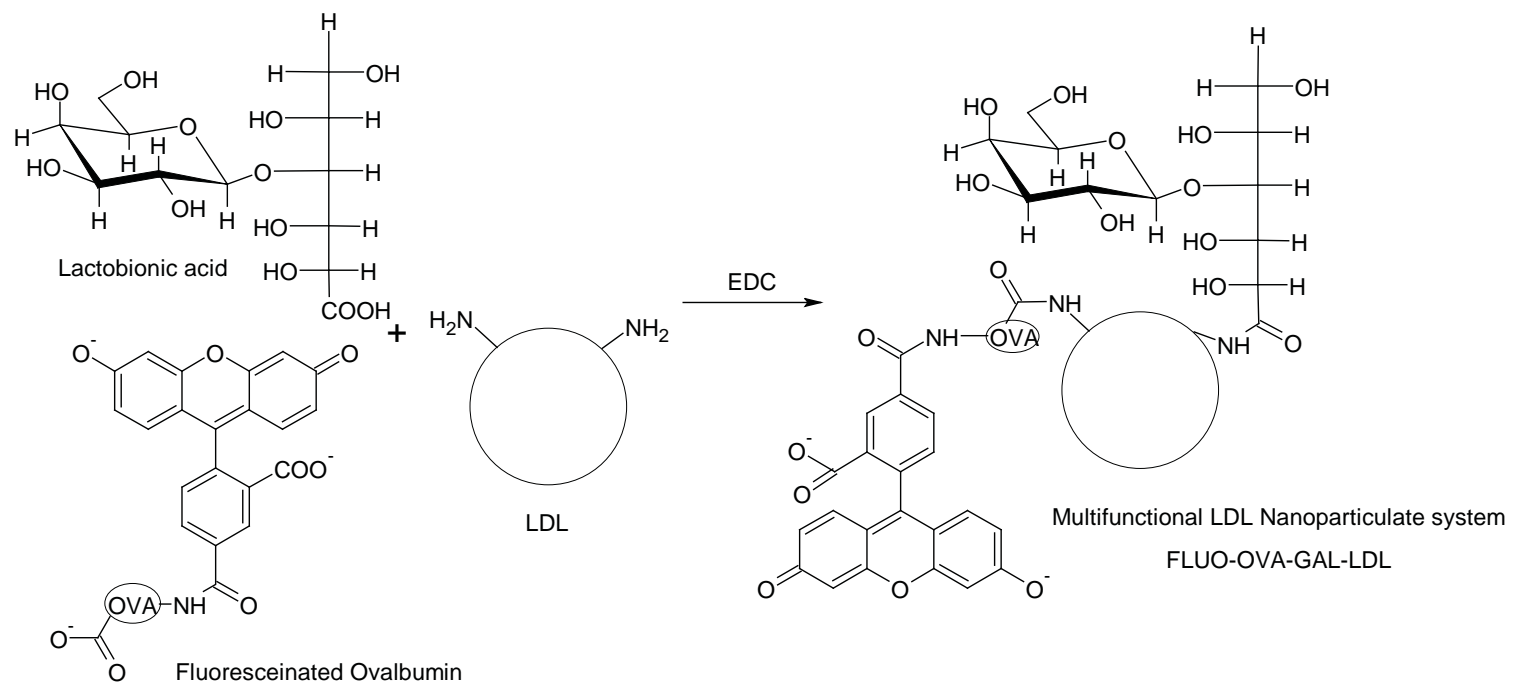

\section{Scheme 4. Scheme of the conjugation method for the preparation of FLUO-OVA-GAL-LDL nanoparticles, where FLUO-OVA - fluoresceinated ovalbumine, LDL - low density lipoprotein, GAL - galactose [27].}

The conjunction resulted in a considerably increased uptake of FLUO-OVA by murine macrophage-like ANA1 cells as compared to NIH-3T3 cells [27]. In order to preserve the biological activity of antigen and maintain the structure and the activity of the ligand, N-ethyl-N'-(3-dimethylaminopropyl) carbodiimide hydrochloride (EDC) has been used to conjugate the primary amine group on the Apo B of LDL particles with the free carboxylic end groups of FLUO-OVA and lactobionic acid, forming connecting amide bonds (Scheme 5).

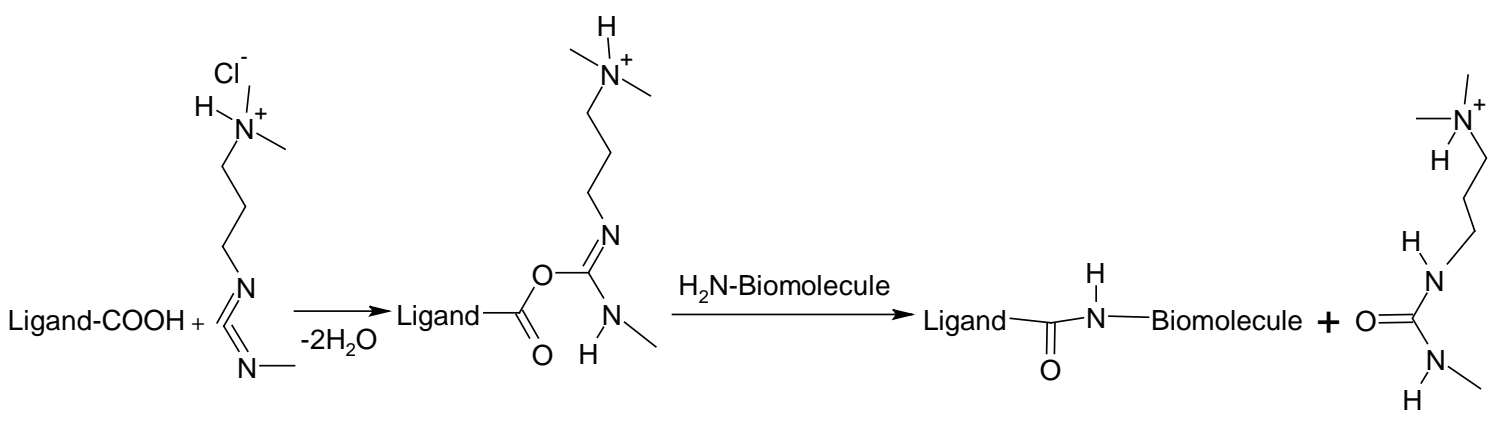

Scheme 5. General scheme of carbodiimide mediated conjunction between a biomolecule and a ligand.

Previously, lactosylated LDL had also been used for targeted delivery of cholesteryl-conjugated phosphorothioate oligodeoxynucleotides to Kupffer cells [28]. A recent study describes development of galactosylated trimethyl chitosancysteine nanoparticles for oral delivery of a mitogen-activated protein kinase kinase kinase kinase 4 siRNA (siMap4k4) to the activated macrophages for treatment of dextran sulphate sodium (DSS)-induced ulcerative colitis [29]. 


\section{Mannose receptors}

Another saccharide, mannose, has been widely applied as ligand targeting macrophage mannose receptors (MRs). The macrophage mannose receptor is an integral membrane protein expressed on the surface of tissue macrophages. After binding of mannose-rich glycoconjugates or pathogens, the receptor mediates endocytosis and phagocytosis of the bound ligands by macrophages [30]. Among the therapeutic systems targeting MRs, mannose-PEG-phosphatidylethanolamine liposomes have been proposed for targeted gene delivery to Kupffer cells [31]. Ligands for these liposomes were synthesized according to the Scheme 6.
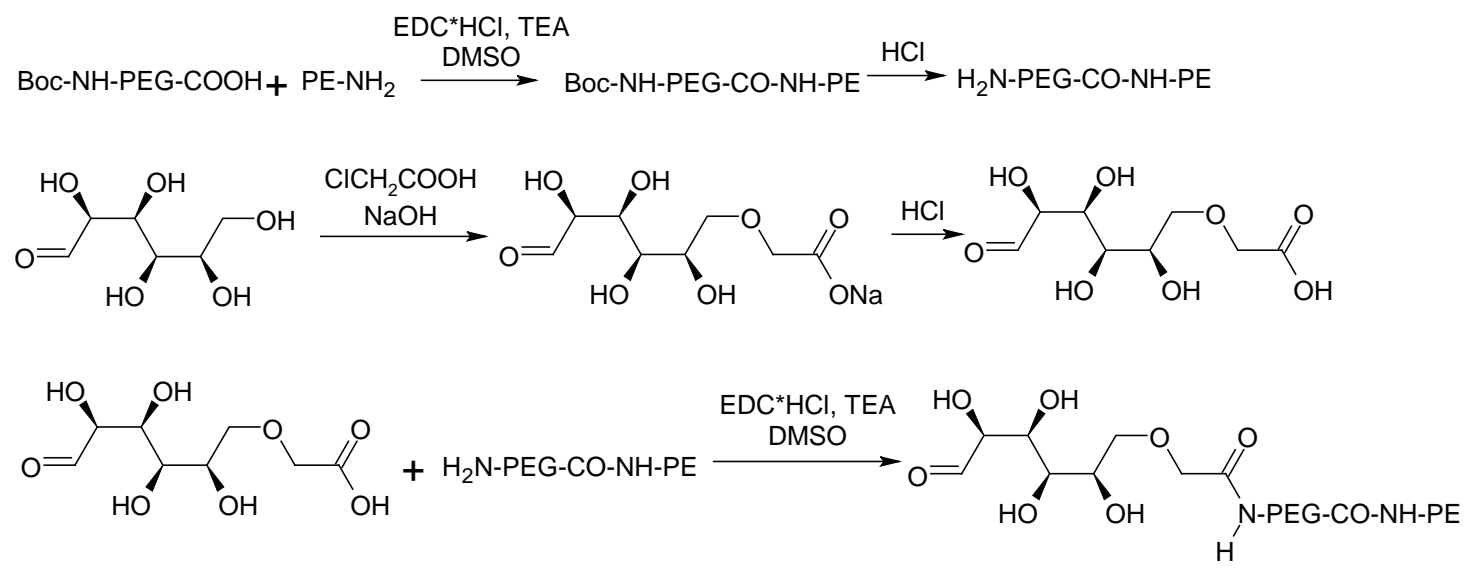

\section{Scheme 6. Synthesis of mannosylated polyethylene glycol-posphatidylethanolamine ligand. Boc-t-butyl carbonyl; PE- $\mathrm{NH}_{2}$-posphatidylethanolamine; PEG-polyethylene glycol; DMSO-dimethyl sulfoxide; TEA-trietanolamine [31].}

Liang et al. [32] reported a drug targeting system which utilized mannose receptor-mediated endocytosis to enhance cellular uptake of antisense oligonucleotides (ONs), being useful for selective inhibition of gene expression, in alveolar macrophages. The system employed a molecular complex consisting of partially substituted mannosylated poly(L-lysine), electrostatically linked to a 5 ' fluorescently labelled ONs. Upon recognition by the macrophage mannose receptors, the MPL was internalized by the receptor-mediated pathway co-transporting the ON. Following cellular internalization, the ON complex appeared largely accumulated in endocytic vesicles. In order to achieve an enhanced endosomal exit of the $\mathrm{ON}$, a fusogenic peptide derived from the amino terminal sequence of influenza virus hemagglutinin HA2 was used. Cytotoxicity studies demonstrated that at the MPL and the fusogenic peptide concentrations effectively enhancing ON uptake, no toxic effects to the cells were observed, thereby suggesting their potential safety and utilization in vivo.

Targeting of mannose receptors has also been achieved through mannan-coating of gelatin nanoparticles designed for didanosine delivery to HIV-infected macrophages [33], manosylation of gelatin nanoparticles [34] and microspheres $[35,36]$ for targeted delivery of isoniazid to Mycobacterium tuberculosis infected alveolar macrophages, manosylation of polyethylenimine coupled mesoporous silica nanoparticles for gene delivery to macrophages [37], mannosylated chitosan microsperes in an adjuvant delivery system for intranasal immunization [38], manosyl-coated nanocomplexes from amphiphilic cyclodextrins (pGaCDs) and pDNA for site specific gene delivery [39].

For example, the latest pGaCD 6 and pGaCD 7 can be prepared following the synthetic schemes in which the key step is the coupling reaction of $\beta C D$ heptaamine $\mathbf{8}$ or heptaisothiocyanate $\mathbf{9}$ with complementary isothiocyanateor amine-armed glycoconjugates (Scheme 7 and Scheme 8). The synthesis of the heterobifunctional antenna in pGaCD 6 starts from the orthogonally protected branching element 10, which after reaction with per-O-acetylated 2-isothiocyanatoethyl- $\alpha$-d-mannopyranoside $\mathbf{1 1}$ transforms into the thiourea adduct $\mathbf{1 2}$ in almost quantitative yield (Scheme 7). Sequential acetyl and trityl cleavage yields amine 13 (97\% over two steps), which then reacts with an excess of 1,6-hexamethylenediisothiocyanate $(\rightarrow \mathbf{1 4}, 52 \%)$. Et ${ }_{3} \mathrm{~N}$-catalysed thiourea-forming reaction between 15 and heptamine 8 in DMF at $40{ }^{\circ} \mathrm{C}$ affords the Boc-protected $\beta C D$ heptaconjugate 16 with yield of $84 \%$. Final carbamate cleavage produces the target pGaCD 6 in quantitative yield.

The synthesis of pGaCD 7 requires isothiocyanate 21 as the aminoglucosyl coating reagent. Its synthesis starts from 6-azidoglucosylenamine 17 (Scheme 8). Reduction of the azido group with 1,3-propanedithiol and protection of the resulting amine $\mathbf{1 8}$ as the corresponding Boc derivative results in carbamate 19. Further O-acetylation ( $\rightarrow \mathbf{2 0})$, enamine chlorolysis, and isothiocyanation with thiophosgene afford isothiocyanate 21 in $54 \%$ overall yield. Compound 21 is first coupled with N-tritylethylene-1,2-diamine, followed by sequential acetyl and trityl cleavage to yield amine 24 (72\% over three steps). Nucleophilic addition of $\mathbf{2 4}$ to heptaisothiocyanate $\mathbf{9}$ in a mixture of DCM-DMF at room 
temperature results in formation of the fully substituted $\beta C D$ adduct $\mathbf{2 5}$, which is subjected to acid-catalyzed carbamate hydrolysis to yield the target heptavalent aminoglycocluster 7 (75\% overall).

An interesting way of targeting mannose receptors has been exploited for macrophage-specific delivery of human glucocerebrosidase (GCase) used in the enzyme replacement therapy of Gaucher disease, one of the most common inherited lysosomal storage disorders [40] caused by a deficiency in the activity of the lysosomal hydrolase GCase. For this, complex oligosaccharides present on GCase have been enzymatically remodeled into a mannose core, facilitating mannose receptor-mediated uptake into macrophages [41]. Interestingly, Van Patten et al. [42] research on the effect of mannose chain length on targeting of macrophage by GCase detected that there is no biochemical or pharmacological advantage in producing enzyme with an increased number of mannose residues.

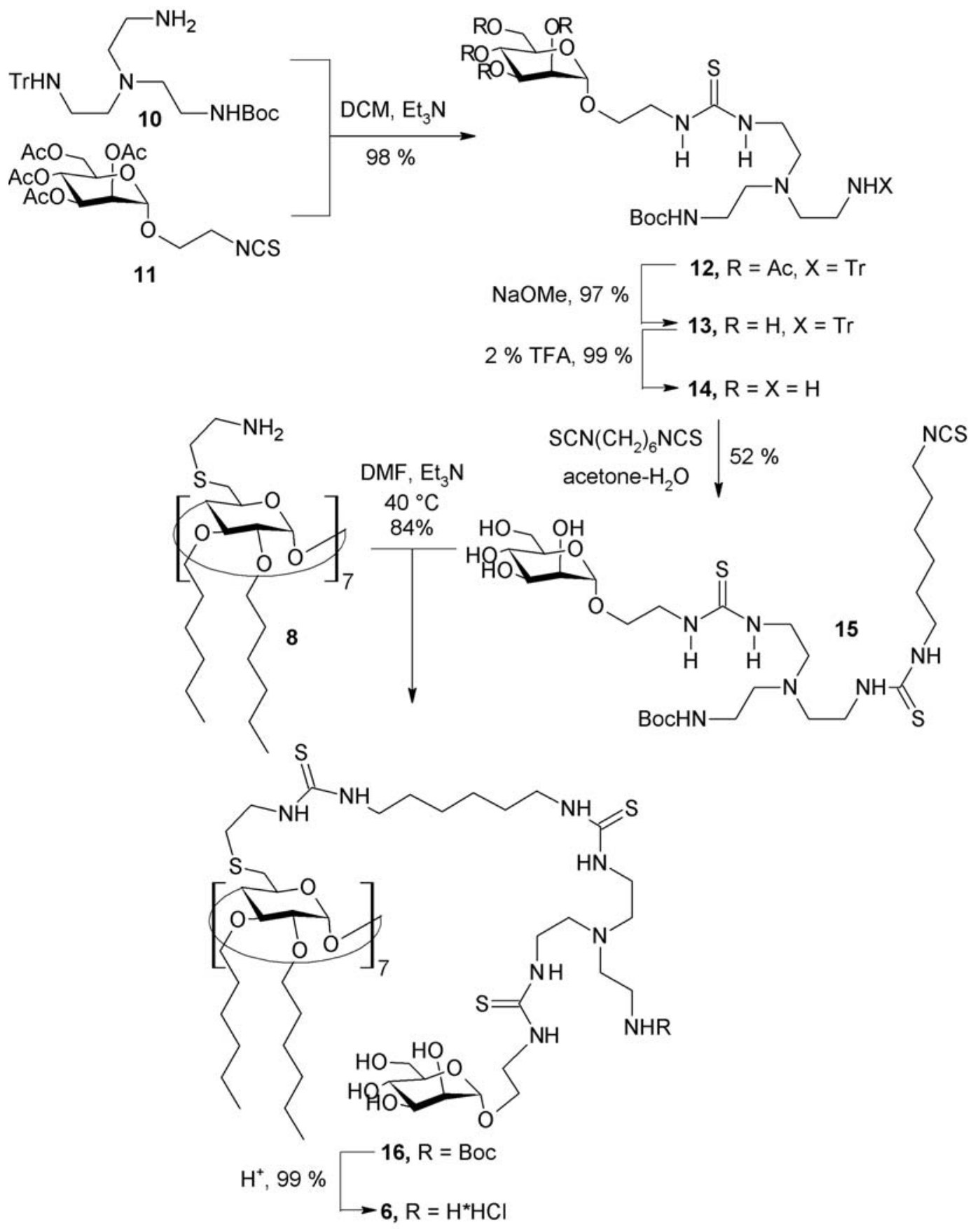

Scheme 7. Synthesis of pGaCD 6 [39]. 


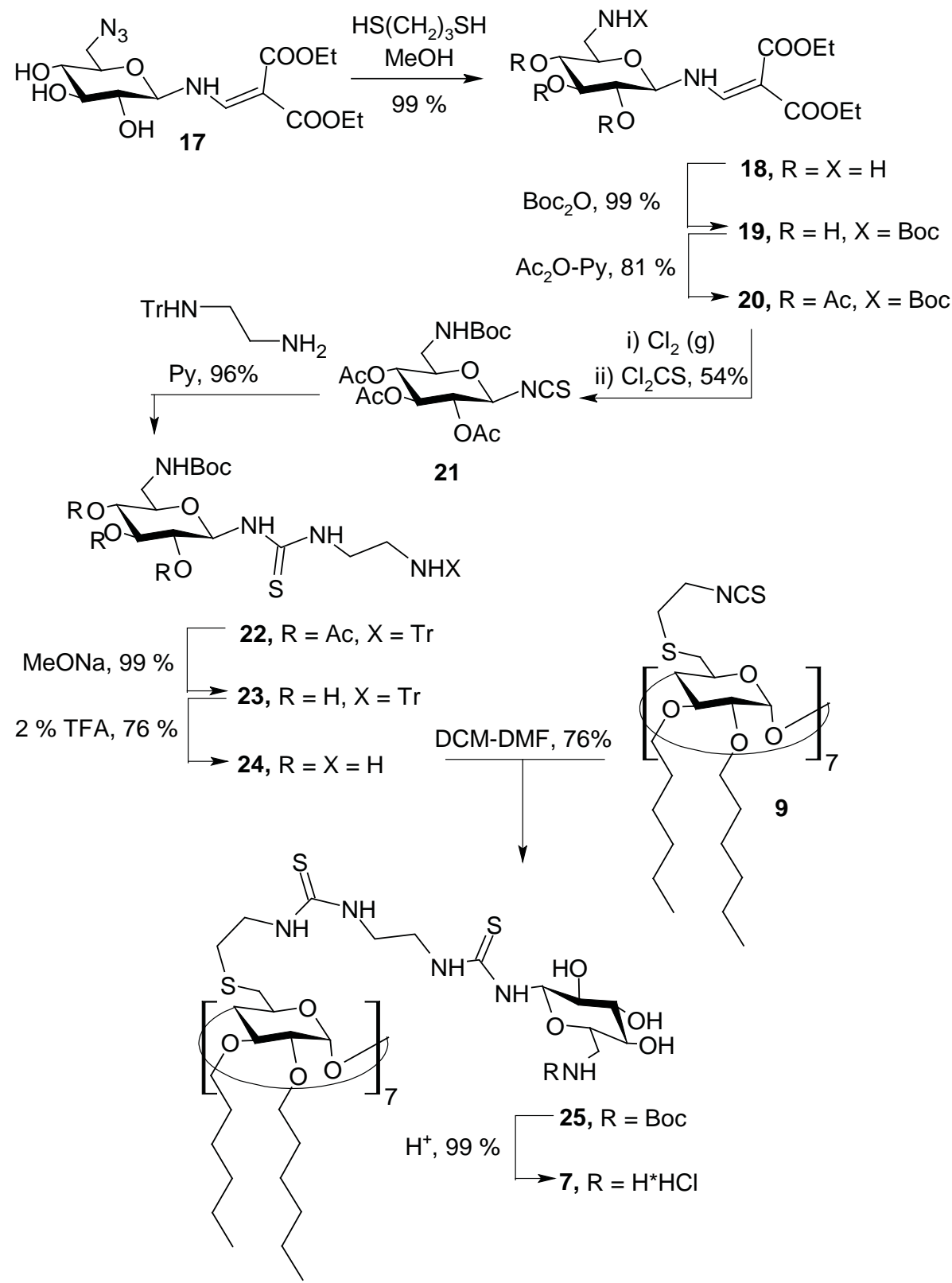

Scheme 8. Synthesis of pGaCD 7 [39].

\section{$\beta$-glucan receptors}

$\beta$-glucan receptors of macrophages have also been demonstrated to be an efficient target for drug delivery. A number of receptors have been implicated in recognition of $\beta$-glucans, including CR3, lactosylceramide, scavenger receptors, and Dectin-1. Cellular recognition is thought to be mediated by combinations of these receptors [43]. At the same time, Brown et al [44] have shown that Dectin-1 acts as a major receptor for zymosan and other $\beta$-glucans on macrophages. Furthermore, through its ability to recognize these carbohydrates, Dectin-1 has been demonstrated to be centrally involved in the innate response to fungal pathogens $[45,46]$.

For the purpose of macrophage targeting through $\beta$-glucan receptors, glucan particles (GPs) derived from the cell walls of baker's yeast (Saccharomyces cerevisiae) have been proposed as drug carriers [47-50]. GPs are hollow, porous 2-4 $\mu \mathrm{m}$ microspheres that can incorporate insoluble preformed nanoparticles as inside cores or drug-containing nanoparticles can be electrostatically bound to the surface of derivatized GPs [50]. As well, loading of soluble drugs inside GPs can be accomplished by incubating GPs with a soluble drug solution in a volume just sufficient to swell the GPs (hydrodynamic volume) with subsequent encapsulation of the drug molecules inside the GPs by physical or chemical trapping [49]. 


\section{Scavenger receptors}

Scavenger receptors (SRs) expressed by macrophages are able to bind modified lipoproteins, senescent and apoptotic cells, proteins, polysaccharides, and a range of polyanionic molecules depending on SRs' classes [51, 52]. These are: Class A-SR-AI, SR-AII, SR-AIII and MARCO (macrophage receptor with a collagenous structure); Class B-CD36, SR-BI/CLA-I and others, such as SR-CI, macrosialin, CD68, LOX-I, SREC [53]. Tempone et al. have proposed application of phosphatidylserine liposomes (PS-LP) for SR-targeted delivery of a pentavalent antimonial, meglumine antimoniate, to macrophages infected with leishmaniasis [54]. Previously, Class A receptor, MARCO and Class B SRs (SRBI and CD36), were shown to be involved in the binding and rapid clearance of PS-LP from the blood compartment [55]. Some of the natural function of SRs Class A include: phagocytosis of bacteria and other pathogens, phagocytosis of apoptotic cells, phagocytosis of senescent red blood cells, endocytosis of oxidized low density lipoprotein and advanced glycation endoproduct-modified proteins, and calcium independent adhesion [56].

Sharma et al. have reported construction of poly-guanine oligonucleotide functionalized nanoparticles with high affinity for SRs of foam cells. Foam cells represent transformed macrophages that play a crucial role in formation of atherosclerotic plaque. This fact highlights the potential utility of macrophage targeted systems in the therapy of atherosclerosis [57].

Targeting of macrophages via SR has been proven effective for cell specific delivery of photosensitizers conjugated with maleylated serum albumin [58-60]. The capability to selectively kill macrophages via photodynamic therapy has applications in treating cancer (tumor-associated macrophages), in the detection and therapy of vulnerable atherosclerotic plaque (foam cells), and possibly for autoimmune disease and some infections [59].

\section{Tuftsin receptors}

Among the peptide-binding macrophage receptors, tuftsin receptor has been well studied for macrophages targeting. Tuftsin is a natural macrophage activator tetrapeptide (Thr-Lys-Pro-Arg) which is a part of the Fc-portion of immunoglobulin-G [61]. It has been proposed to be used in conjunction with AZT for targeting HIV-infected macrophages [62]. The scheme of tuftsinyl-AZT synthesis is presented in Scheme 9.

Tuftsin has also been proposed for decoration of liposomes as drug carriers for the treatment of macrophagebased infections: fungal infections, leishmaniasis, malaria, tuberculosis [63].

Fmoc-Arg(Pmc)-OH + AZT-OH DCC / DMZP (80 \%)

Fmoc-Arg(Pmc)-OH-AZT

Morpholine (75 \%)

Boc-Thr-Lys(Boc)-Pro-OSu

$\mathrm{H}-\mathrm{Arg}(\mathrm{Pmc})-\mathrm{OH}-\mathrm{AZT}$

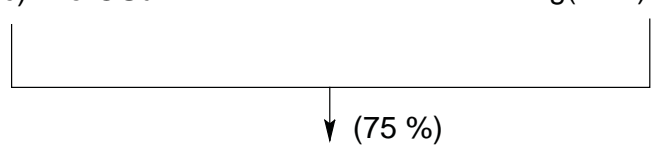

Boc-Thr-Lys(Boc)-Pro-Arg(Pmc)-O-AZT

$\operatorname{TFA}(75 \%)$

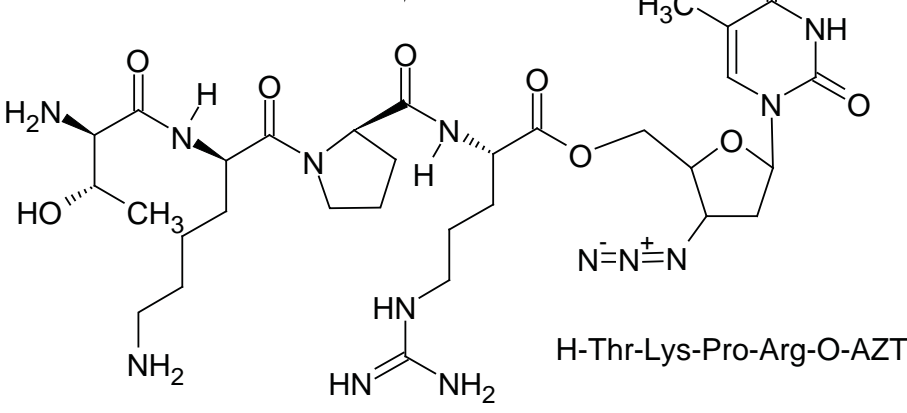

Scheme 9. Synthesis of tuftsinyl-AZT (numbers in parentheses refer to synthetic yields) [62]. 


\section{Targeting specific macrophage enzymes}

Another possible way of targeting macrophage is targeting of macrophage specific enzymes that would selectively activate the drug via hydrolysis inside the cell. The main advantage of this approach in comparison with macromolecular targeting systems is that it can be applied to multiple drug types administrable by mouth on a long-term basis [64].

One of the targeted enzymes can be human carboxylesterase-1 (hCE-1). The cells of monocyte/macrophage lineage are the principal source of the enzyme outside the hepatocyte $[65,66]$. Needham et al. have focused their studies on the identification of an amino acid ester motif that was selectively hydrolyzed by hCE-1 [64]. They have investigated the following amino acid ester motifs that would be selectively hydrolyzed by hCE-1 (Figure 1): phenylalanine cyclopentyl 26 and $t$-butyl esters 27, leucine cyclopentyl 28 and $t$-butyl esters 29.<smiles>[R]NC(Cc1ccccc1)C(=O)OC1CCCC1</smiles>

26<smiles>[R]N([2H])[C@@H](CC(C)C)C(=O)OC1CCCC1</smiles>

28<smiles>[R]N([2H])[C@H](Cc1ccccc1)C(=O)OC(C)(C)C</smiles>
27<smiles>[R]N([2H])[C@@H](CC(C)C)C(=O)OC(C)(C)C</smiles>

29

Figure 1. Amino acid ester motifs for macrophage targeting investigated by Needham et al. [64].

An example of drug candidate with phenylalanine cyclopentyl ester motif selectively targeting macrophages/ monocytes is tefinostat ( $S$-[4-(7-hydroxycarbamoylheptanoylamino)-benzylamino]-phenylacetic acid cyclopentyl ester, CHR-2845), a histone deacetylase inhibitor (HDACi) that has already passed phase I first-in-human clinical trial [67].

\section{Conclusions}

The small molecule-recognition concepts applied for macrophage targeting and described here have different advantages and disadvantages. The main disadvantage of the macromolecular, nano- and microparticulate systems decorated with macrophage targeting ligands is often impossibility of their oral administration. From this point of view, application of small molecule motifs attached directly to the drug molecule is more advantageous. If compared with antibody-attached systems, ligand-decorated systems and medicines with small molecule motifs have lower level of selectivity in targeting macrophages. At the same time, medicines with small molecule motifs, if compared to antibodyattached and ligand-decorated microparticulate systems, have lower cost and simplicity in obtaining.

Generally, the small molecule-recognition concepts have a good potential in design and development of new medicines for diagnosis and treatment of cancer, macrophage resident infections, and inflammatory diseases.

Acknowledgments: a part of this research has been funded in the framework of 13.820.19.07 STCU.A/5800 project.

\section{References}

[1] Seljelid, R.; Eskeland, T. Eur. J. Haematol. 1993, 51, pp. 267-275.

[2] Rogers, T. L.; Holen, I. J. Transl. Med. 2011, 9, 177 p.

[3] Richards, D. M.; Hettinger, J.; Feuerer, M. Cancer Microenviron. 2013, 6, pp. 179-191.

[4] Linton, M. F.; Fazio, S. Int. J. Obes. 2003, 27, pp. S35-S40.

[5] Lewis, C. E.; Pollard, J. W. Cancer Res. 2006, 66, pp. 605-612.

[6] Schnappinger, D.; Ehrt, S.; Voskuil, M. I.; Liu, Y.; Mangan, J. A.; Monahan, I. M.; Dolganov, G.; Efron, B.; Butcher, P. D.; Nathan, C.; Schoolnik, G. K. J. Exp. Med. 2003, 198, pp. 693-704.

[7] Carter, C. A.; Ehrlich, L. S. Annu. Rev. Microbiol. 2008, 62, pp. 425-443.

[8] Handman, E.; Bullen, D. V. Trends Parasitol. 2002, 18, pp. 332-334.

[9] Miller, J. L.; M deWet, B. J.; Martinez-Pomares, L.; Radcliffe, C. M.; Dwek, R. A.; Rudd, P. M.; Gordon, S. PLoS Pathog. 2008, 4, e17. 
[10] Ahsan, F.; Rivas, I. P.; Khan, M. A.; Torres Suárez, A. I. J. Controlled Release. 2002, 79, $29-40$.

[11] Crocker, P. R.; Mucklow, S.; Bouckson, V.; McWilliam, A.; Willis, A. C.; Gordon, S.; Milon, G.; Kelm, S.; Bradfield, P. EMBO J. 1999, 13, pp. 4490-4603.

[12] Hartnell, A.; Steel, J.; Turley, H.; Jones, M.; Jackson, D. G.; Crocker, P. R. Blood. 2001, 97, pp. $288-296$.

[13] Nakamura, K.; Yamaji, T.; Crocker, P. R.; Suzuki, A.; Hashimoto, Y. Glycobiology. 2002, 12, pp. $209-216$.

[14] Munday, J.; Floyd, H.; Crocker, P. R. J. Leukocyte Biol. 1999, 66, pp. 705-711.

[15] Chen, W. C.; Kawasaki, N.; Nycholat, C. M.; Han, S.; Pilotte, J.; Crocker, P. R.; Paulson, J. C. PloS one. 2012, 7, e39039.

[16] Nycholat, C. M.; Rademacher, C.; Kawasaki, N.; Paulson, J. C. J. Am. Chem. Soc. 2012, 134, pp. 15696-15699.

[17] Magesh, S.; Ando, H.; Tsubata, T.; Ishida, H.; Kiso, M. Curr. Med. Chem. 2011, 18, pp. 3537-3550.

[18] Thomas, T. P.; Goonewardena, S. N.; Majoros, I.; Kotlyar, A.; Cao, Z.; Leroueil, P. R.; Baker Jr., J. R. Arthritis Rheum. 2011, 63, pp. 2671-2680.

[19] Chandrasekar, D.; Sistla, R.; Ahmad, F. J.; Khar, R. K.; Diwan, P. V. Biomaterials. 2007, 28, pp. 504-512.

[20] Turk, M. J.; Waters, D. J.; Low, P. S. Cancer Lett. 2004, 213, pp. 165-172.

[21] Turk, M. J.; Breur, G. J.; Widmer, W. R.; Paulos, C. M.; Xu, L. C.; Grote, L. A.; Low, P. S. Arthritis Rheum. 2002 , 46, pp. 1947-1955.

[22] Paulos, C. M.; Turk, M. J.; Breur, G. J.; Low, P. S. Folate receptor-mediated targeting of therapeutic and imaging agents to activated macrophages in rheumatoid arthritis. Adv. Drug Delivery Rev. 2004, 56, pp. 1205-1217.

[23] Gent, Y. Y.; Weijers, K.; Molthoff, C. F.; Windhorst, A. D.; Huisman, M. C.; Smith, D. E.; Kularatne, S. A.; Jansen, G.; Low, P. S.; Lammertsma, A. A.; van der Laken, C. J. Arthritis Res. Ther. 2013, 15, R37.

[24] Shimada, K.; Kamps, J. A.; Regts, J.; Ikeda, K.; Shiozawa, T.; Hirota, S.; Scherphof, G. L. Biochim. Biophys. Acta, Biomembr. 1997, 1326, pp. 329-341.

[25] Haensler, J.; Schuber, F. Biochim. Biophys. Acta, Biomembr. 1988, 946, pp. 95-105.

[26] Haensler, J.; Schuber, F. Glycoconjugate J. 1991, 8, pp. 116-124.

[27] Wu, F.; Wuensch, S. A.; Azadniv, M.; Ebrahimkhani, M. R.; Crispe, I. N. Mol. Pharm. 2009, 6, pp. $1506-1517$.

[28] Bijsterbosch, M. K.; Manoharan, M.; Dorland, R.; Waarlo, I. H.; Biessen, E. A.; van Berkel, T. J. Biochem. Pharmacol. 2001, 62, 627-633.

[29] Zhang, J.; Tang, C.; Yin, C. Biomaterials. 2013, 34, 3667-3677.

[30] Ezekowitz, R. A.; Sastry, K.; Bailly, P.; Warner, A. J. Exp. Med. 1990, 172, 1785-1794.

[31] Kong, F.; Zhou, F.; Ge, L.; Liu, X.; Wang, Y. Int. J. Nanomedicine. 2012, 7, 1079-1089.

[32] Liang, W.; Shi, X.; Deshpande, D.; Malanga, C. J.; Rojanasakul, Y. Biochim. Biophys. Acta, Biomembr. 1996, 1279 , pp. 227-234.

[33] Kaur, A.; Jain, S.; Tiwary, A. K. Act. Pharm. 2008, 58, pp. 61-74.

[34] Saraogi, G. K.; Sharma, B.; Joshi, B.; Gupta, P.; Gupta, U. D.; Jain, N. K.; Agrawal, G. P. J. Drug Targeting. 2011, 19, pp. 219-227.

[35] Tiwari, S.; Chaturvedi, A. P.; Tripathi, Y. B.; Mishra, B. AAPS PharmSciTech. 2011, 12, pp. 900-908.

[36] Tiwari, S.; Chaturvedi, A. P.; Tripathi, Y. B.; Mishra, B. Carbohydr. Polym. 2012, 87, pp. 1575-1582.

[37] Park, I. Y.; Kim, I. Y.; Yoo, M. K.; Choi, Y. J.; Cho, M. H.; Cho, C. S. Int. J. Pharm. 2008, 359, pp. 280-287.

[38] Jiang, H. L.; Kang, M. L.; Quan, J. S.; Kang, S. G.; Akaike, T.; Yoo, H. S.; Cho, C. S. Biomater. 2008, 29, pp. 1931-1939.

[39] Díaz-Moscoso, A.; Guilloteau, N.; Bienvenu, C.; Méndez-Ardoy, A.; Jiménez Blanco, J. L.; Benito, J. M.; Le Gourriérec, L.; Di Giorgio, C.; Vierling, P.; Defaye, J.; Ortiz Mellet, C.; García Fernández, J. M. Biomaterials. 2011, 32, pp. 7263-7273.

[40] Beutler, E. Gaucher disease. Blood Rev. 1988, 2, pp. 59-70.

[41] Barton, N. W.; Furbish, F. S.; Murray, G. J.; Garfield, M.; Brady, R. O. Proc. Natl. Acad. Sci. U. S. A. 1990, 87 , pp. 1913-1916.

[42] Van Patten, S. M.; Hughes, H.; Huff, M. R.; Piepenhagen, P. A.; Waire, J.; Qiu, H.; Ganesa, C.; Reczek, D.; Ward., P.W.; Kutzko, J.P.; Edmunds, T. Glycobiology. 2007, 17, pp. 467-478.

[43] Brown, G. D.; Gordon, S. Cell. Microbiol. 2005, 7, pp. 471-479.

[44] Brown, G. D.; Taylor, P. R.; Reid, D. M.; Willment, J. A.; Williams, D. L.; Martinez-Pomares, L.; Wong, S.Y.C.; Gordon, S. J. Exp. Med. 2002, 196, pp. 407-412.

[45] Brown, G. D.; Herre, J.; Williams, D. L.; Willment, J. A.; Marshall, A. S.; Gordon, S. J. Exp. Med. 2003, 197, pp. 1119-1124.

[46] Taylor, P. R.; Tsoni, S. V.; Willment, J. A.; Dennehy, K. M.; Rosas, M.; Findon, H.; Haynes, K.; Steele, C.; Botto, M.; Gordon. S.; Brown, G. D. Nat. Immunol. 2006, 8, pp. 31-38.

[47] Jamas, S.; Ostroff, G. R.; Easson Jr, D. D. U.S. Patent No. 5,032,401. Washington, DC: U.S. Patent and Trademark Office. 16.07.1991. 
[48] Aouadi, M.; Tesz, G. J.; Nicoloro, S. M.; Wang, M.; Soto, E.; Ostroff, G. R.; Czech, M. P. Nature. 2009, 458, pp. 1180-1184.

[49] Soto, E. R.; Kim, Y. S.; Lee, J.; Kornfeld, H.; Ostroff, G. R. Polym. 2010, 2, pp. 681-689.

[50] Soto, E. R.; Caras, A. C.; Kut, L. C.; Castle, M. K.; Ostroff, G. R. J. Drug Deliv. 2011, 2012 , ID143524.

[51] Peiser, L.; Mukhopadhyay, S.; Gordon, S. Curr. Opin. Immunol. 2002, 14, pp. 123-128.

[52] Mukhopadhyay, S.; Gordon, S. Immunobiology. 2004, 209, pp. 39-49.

[53] Shirai, H.; Murakami, T.; Yamada, Y.; Doi, T.; Hamakubo, T.; Kodama, T. Mech. Ageing Dev. 1999, 111, pp. 107-121.

[54] Tempone, A. G.; Perez, D.; Rath, S.; Vilarinho, A. L.; Mortara, R. A.; de Andrade, H. F. J. Antimicrob. Chemother. 2004, 54, pp. 60-68.

[55] Nishikawa, K.; Arai, H.; Inoue, K. J. Biol. Chem. 1990, 265, pp. 5226-5231.

[56] Yamada, Y.; Doi, T.; Hamakubo, T.; Kodama, T. Cell. Mol. Life Sci. 1995, 54, pp. 628-640.

[57] Sharma, G.; She, Z. G.; Valenta, D. T.; Stallcup, W. B.; Smith, J. W. Nano Life. 2010, 1, pp. $207-214$.

[58] Hamblin, M. R.; Miller, J. L.; Ortel, B. Photochem. Photobiol. 2000, 72, pp. 533-540.

[59] Demidova, T. N.; Hamblin, M. R. Int. J. Immunopathol. Pharmacol. 2004, 17, pp. 117-126.

[60] Anatelli, F.; Mroz, P.; Liu, Q.; Yang, C.; Castano, A. P.; Swietlik, E.; Hamblin, M. R. Mol. Pharmaceutics. 2006, 3, pp. 654-664.

[61] Fridkin, M.; Najjar, V. A. Crit. Rev. Biochem. Mol. Biol. 1989, 24, pp. 1-40.

[62] Fridkin, M.; Tsubery, H.; Tzehoval, E.; Vonsover, A.; Biondi, L.; Filira, F.; Rocchi, R. J. Pept. Sci. 2005, 11, pp. 37-44.

[63] Agrawal, A. K.; Gupta, C. M. Adv. Drug Delivery Rev. 2000, 41, pp. 135-146.

[64] Needham, L. A.; Davidson, A. H.; Bawden, L. J.; Belfield, A.; Bone, E. A.; Brotherton, D. H.; Bryant, S.; Charlton, M. H.; Clark, V. L.; Davies, S. J.; Donald, A.; Day, F. A.; Krige, D.; Legris, V.; McDermott, J.; McGovern, Y.; Owen, J.; Patel, S. R.; Pintat, S.; Testar, R. J.; Wells, G. M. A.; Moffat, D.; Drummond, A. H. J. Pharmacol. Exp. Ther. 2011, 339, pp. 132-142.

[65] Satoh, T.; Hemmerlein, B.; Zschunke, F.; Radzun, H.J. Pathobiology. 1999, 67, 158-162.

[66] Uphoff, C. C.; Drexler, H. G. Leuk. Lymphoma. 2000, 39, pp. 257-270.

[67] Ossenkoppele, G. J.; Lowenberg, B.; Zachee, P.; Vey, N.; Breems, D.; Vandeloosdrecht, A. A.; Davidson, A. H.; Wells, G.; Needham, L.; Bawden, L.; Toal, M.; Hooftman, L.; Debnam, P. M. Br. J. Haematol. 2013, 162, pp. $191-201$. 